\title{
A STUDY ON HARVESTING MECHANIZATION OF SOYBEAN CROP
}

Gomaa, S.M. ${ }^{1}$; R.R. Abu-Shieshaa ${ }^{2}$; F.I. Hindy ${ }^{1}$ and M.A. Hassan ${ }^{2}$

1- Agric. Eng. Dept., Fac. of Agric., Kafrelsheikh Univ.

2- Agric. Eng. Res. Inst., Agric. Res. Center., Giza.

\begin{abstract}
The experiments were carried out during the agricultural season of 2003 to evaluate two different systems of harvesting soybean crop to choose the most efficient and economic system as well as to determine the optimum operating conditions for both systems. The first system was harvesting soybean crop by combine harvester (Yanmar-CA760) which was tested at four different forward and cylinder speeds under four various levels of grain and straw moisture contents. The second was harvested by hand sickle then threshed, winnowed by Turkish threshing machine that was tested at four feed rates and cylinder speeds under the same above mentioned moisture contents. All experiments were performed at the research farm of Rice Mechanization Center, Meet El-Deeba, Kafr El-Sheikh Governorate.

Results showed that combine harvester (Yanmar-CA760) is strongly recommended since it gave lower losses, damage, costs and higher performance efficiency compared to manual harvesting and gathering followed by mechanical threshing and winnowing using Turkish thresher. The optimum operating conditions for combine harvester (Yanmar-CA760) are at forward speed of $2.6 \mathrm{~km} / \mathrm{h}$, cylinder speed of $10.89 \mathrm{~m} / \mathrm{s}$ and grain moisture content of $18.50 \%$. However, the optimum operating conditions for manual harvesting and gathering followed by mechanical threshing and winnowing using Turkish thresher was at feed rate of $0.5 \mathrm{~kg} / \mathrm{s}$, cylinder speed of $11.99 \mathrm{~m} / \mathrm{s}$ and grain moisture content of $18.50 \%$.
\end{abstract}

\section{INTRODUCTION}

Soybean is considered as the most important oil crop in the world. In Egypt, soybean crop is not only an oil crop but also a ready source of protein for people diet, chickens and animals). It is well known that the lack of edible oil production is one of the greatest problems that Egypt has suffered from since the last decade. One of the major problems associated with the production of soybeans is field loss at harvest. In Egypt, harvesting and threshing soybean crop is still done manually which is tedious and timeconsuming with high losses (Abd El-Motaleb et al., 1999). The average soybean harvesting losses are generally more than 8 percent and that over 80 percent of these losses are caused by the combine header (Nave et al. (1973).

Mechanical damage of seeds during harvesting and handling processes is a major concern of the seed industries. Seed damage results in lower seed yield, storability problems, and reduced seed germination and seedling vigor (McDonald, 1985). Soybean seeds are particularly susceptible to mechanical damage because of their large size and mass, and because of the two cotyledons are easily split apart. Much of the damage is the result of seed impact with high velocity threshing and conveying mechanisms. The 
great importance of this crop and the great loss and damage during harvesting make it necessary to have a study on harvesting soybean crop.

Mesquita (1994) stated that, losses during harvesting can be categorized as pre-harvest losses, threshing losses, separating losses and header losses. Pre-harvest losses can be minimized by harvesting soybean at the correct moisture content. Abd El-Motaleb et al. (1999) mentioned that increasing the forward speed from 1.7 to $4.9 \mathrm{~km} / \mathrm{h}$, increased the total losses of soybean crop by $55.43,61.54$ and $56.11 \%$ for seed moisture contents 13.56, 19.07 and $30.50 \%$, respectively for combine harvester CaseInternational Model 1620.

Dunn et al. (1973) showed that under field conditions when soybean moisture was less than $13 \%, 81 \%$ of the harvesting loss resulted from the cutterbar when the crop was cut to leave a stubble height of $8.9 \mathrm{~cm}$ (3.5 in.). the auger was responsible for $13 \%$ of the loss and the reel for the remaining $6 \%$. They also added that the shatter loss was greater than either of the other loss categories. The total header loss, shatter and stalk losses accounted for 64.1 and $31.2 \%$ respectively. Tandon and Panwar (1989) found that header losses represent $80 \%$ of all soybean losses and consisted of $61 \%$ shatter loss, $22 \%$ lodging and stalk loss, and $17 \%$ stubble loss.

Vejasit and Salokhe (2004) showed the effect of drum speed, feed rate and moisture content on the threshing efficiency for soybean crop. They indicated that threshing efficiency was between 98.35 to $99.49 \%$, these results were due to low pod cohesion at the range of soybean moisture content tested. Sharma and Devnani (1980) carried out threshing studies on soybean and cowpea, they found that the feed rate increased with the increase in cylinder tip speed at all concave clearances, which resulted in subsequently higher grain output. The threshing efficiency was affected by cylinder tip speed, concave clearance and the quantity of material passed through the thresher per hour (feed rate).

Baiomy et al. (1999) studied the performance of AMRI and Gabr threshers for soybean. The final results indicated that the best performance of AMRI and Gabr threshers were found at drum speed of 14 (400) and 12 (339) $\mathrm{m} / \mathrm{s}$ (r.p.m) respectively. Fernando et al. (2004) developed and tested soybean threshing mechanism. They found that seed breakage and seed coat damage increased with increasing shaft rotational speeds of the threshing mechanism.

Jung (1988) reported that during harvesting soybean some beans may not be removed from the pods by the cylinder, due to high moisture content or incorrect cylinder-concave setting, $0.5 \%$ of the crop may be lost in this way but it is generally possible to eliminate the loss entirely, without the risk of over threshing which might damage some beans.

The objectives of the present study were to measure the total harvesting losses of soybean grain, to evaluate and choose the most efficient and economic system for harvesting and threshing soybean crop. 


\section{Materials:}

\section{MATERIALS AND METHODS}

\section{1) The combine ( Yanmar - CA 760 )}

A Japanese made combine harvester model (Yanmar-CA 760) were used in the present study. Technical data and specifications are indicated in Table 1 and Fig. 1.

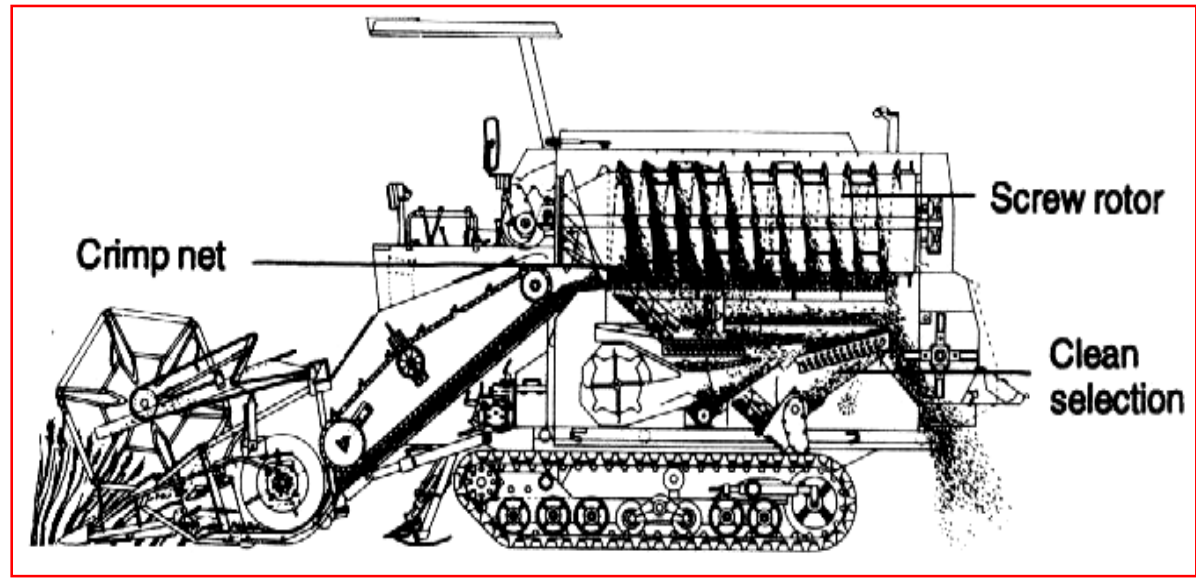

Fig. 1: Cross section view of combine harvester (Yanmar-CA760).

Table 1: Combine specifications

\begin{tabular}{|c|c|c|}
\hline \multicolumn{2}{|r|}{ Model } & CA760-T \\
\hline \multirow[t]{3}{*}{ Dimensions } & Overall length, $\mathrm{mm}$ & 5600 \\
\hline & Overall width, mm & 2430 (2180 at transport) \\
\hline & Overall height, $\mathrm{mm}$ & 2650 (2265 at transport) \\
\hline \multicolumn{2}{|l|}{ Running weight, kg } & 3910 \\
\hline \multirow[t]{3}{*}{ Engine } & Model & YANMAR 4TN100 \\
\hline & Type & $\begin{array}{l}\text { Water-cooled, 4-cycle, Vertical 4- } \\
\text { cylinder diesel engine }\end{array}$ \\
\hline & Output, kW (r.p.m) & $57(2600)$ \\
\hline \multirow[t]{4}{*}{ Traveling section } & Type & Full crawler (rubber) \\
\hline & $\begin{array}{l}\text { Crawler size }(\text { Width } \times \text { ground } \\
\text { contact length }), \mathrm{mm}\end{array}$ & $500 \times 1710$ \\
\hline & \begin{tabular}{|l|} 
Traveling $\quad$ Forward, $\mathrm{m} / \mathrm{sec}$ \\
\end{tabular} & $0 \sim 2.3$ \\
\hline & Reverse, $\mathrm{m} / \mathrm{sec}$ & $0 \sim 1.5$ \\
\hline \multirow[t]{2}{*}{ Header } & Type & Platform and auger \\
\hline & Harvest width, mm & 2060 \\
\hline \multirow[t]{3}{*}{ Threshing section } & Type & Screw rotor \\
\hline & Dia. $\times$ length, $\mathrm{mm}$ & $650 \times 2170$ \\
\hline & Rotor speed, r.p.m & $\begin{array}{l}716 \text { (rice, wheat, barley), } 325 \\
\text { (soybean) }\end{array}$ \\
\hline \multirow[t]{3}{*}{ Separating section } & Separating system & Suction air and shaking sieve \\
\hline & Chaff sieve area, $\mathrm{m}^{2}$ & 1.24 \\
\hline & Grain sieve area, $\mathrm{m}^{2}$ & 0.22 \\
\hline \multicolumn{2}{|c|}{ Grain handing system } & Bagging type \\
\hline \multicolumn{2}{|c|}{ Straw disposal system } & Straw spreader (option) \\
\hline
\end{tabular}


Gomaa, S.M. et al.

\section{2) Turkish threshing machine:}

This machine essentially consists of two components fitted to a steel frame supported by two tire wheels and one vertical link. The two components are: threshing unit and winnowing unit (separating and cleaning) of grain. Technical data and specifications of Turkish threshing machine are indicated in Table 2 and Fig. 2. A2WD (Nassr DM 34) was used to operating the threshing machine. The tractor power used is $44.77 \mathrm{~kW}$ (60 hp).Diesel engine.

Table 2: Technical data and specifications of Turkish threshing machine

\begin{tabular}{|l|l|}
\hline Manufacture & Turkey \\
\hline Length & $325 \mathrm{~cm}$ without hitch, $420 \mathrm{~cm}$ with hitch \\
\hline Width & $131 \mathrm{~cm}$ \\
\hline Height & $198 \mathrm{~cm}$ \\
\hline Source of power & Transmit from tractor through pulley and belt \\
\hline Threshing drum: & $70 \mathrm{~cm}$ \\
Drum diameter & $120 \mathrm{~cm}$ \\
Length & $118 \times 50 \mathrm{~cm}$ \\
\hline Feed opening & $17 \mathrm{per}\left(10 \times 10 \mathrm{~cm}^{2}\right)$ \\
\hline Concave: & $1.8 \mathrm{~cm}$ \\
Number of concave holes & $3.5 \mathrm{~cm}$ \\
Hole diameter & $10 \mathrm{~mm}$ \\
Concave clearance & $40 \mathrm{per}\left(10 \times 10 \mathrm{~cm}^{2}\right)$ \\
\hline Grain-winnowing: & \\
Hole of vibrating screen, diameter & Number of holes
\end{tabular}

\section{3) Miscellaneous equipment:}
a) Electrical oven.
b) Measuring tape

c) Sickles for manual harvesting.

d) Balance.

f) Several square frames made from wood.

e) Long sheet of canvas.

g) Photo sensing tachometer: was used for measuring the cylinder speed (Japanese make).

h) The Screen: The unthreshed grain were separated from the threshed grain by means of the hand operated screen.

\section{4) Experimental procedure:}

The experiments were carried out during the agricultural season of 2003 in order to evaluate two different systems of harvesting soybean crop and determine the optimum operating conditions for both harvesting systems. The first system was harvesting soybean crop by combine harvester (Yanmar-CA760) which was tested at four different forward speeds of 1.4, $1.9,2.6$ and $3.1 \mathrm{~km} / \mathrm{h}$, four cylinder speeds of 9.87 (290), 10.89 (320), 12.59 (370) and 13.95 (410) m/s (r.p.m) which obtained by using different pulleys and four moisture contents for both grain and straw of 22.41, 18.50, 14.96, 12.14 and $40.52,31.34,20.50,14.82 \%$ respectively. 

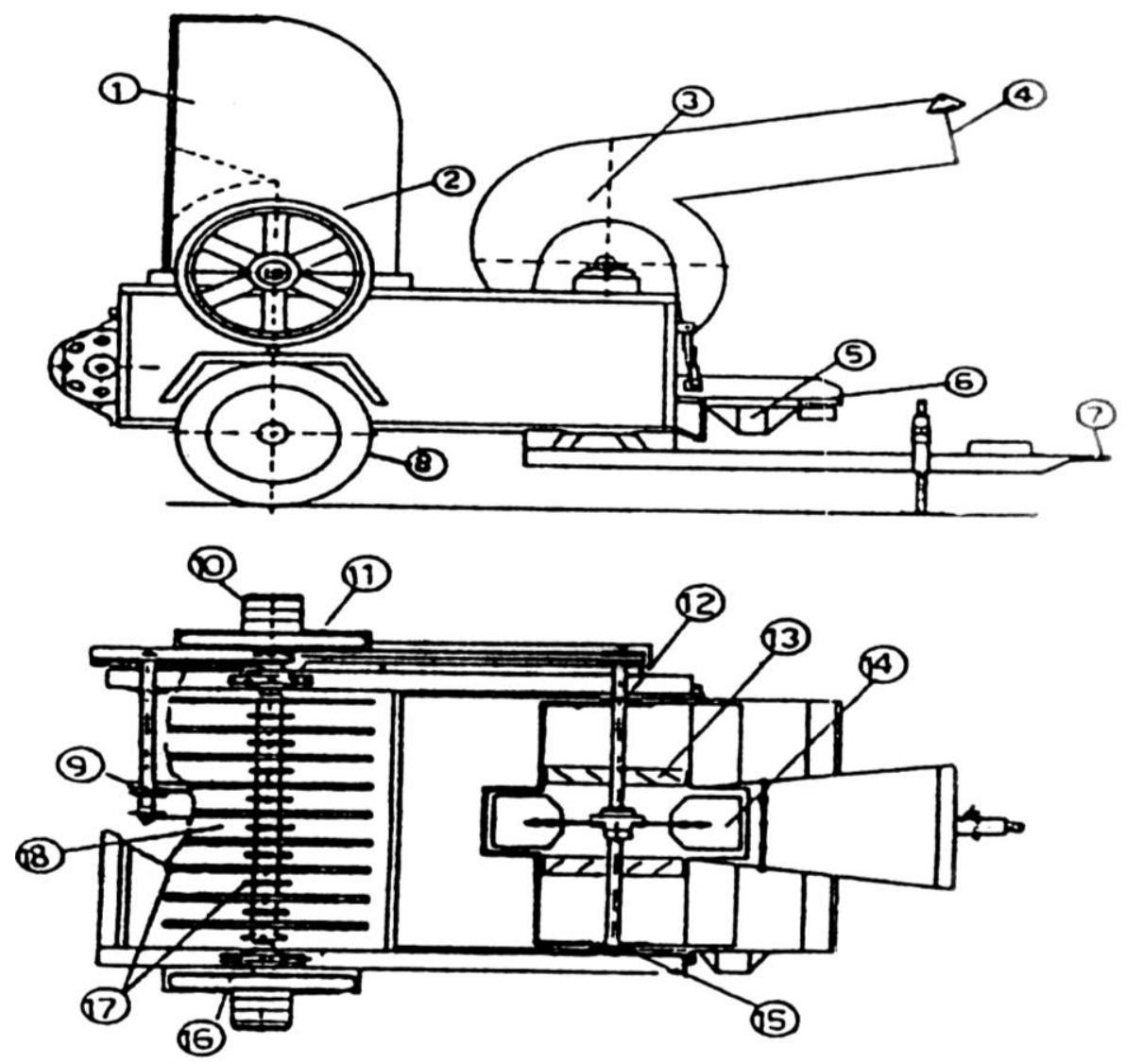

Fig. 2: Main components of Turkish threshing machine.

1. Feeding opening.

7. Latch point.

13. Separator wing.

2. Threshing unit.

8. Tire wheel.

14. Paddle wheel.

3. Centrifugal fan.

9.Crank mechanism.

15. Bearing of fan shaft.

4. Output straw opening.

10. Pulley drum.

16. Bearing of drum shaft.

5. Output grain opening.

11. Flywheel.

17. Beater fingers of drum.

6 . Vibrating screen.

12. Fan shaft

18. Concave grate.

The second system was harvested by hand sickle then threshed, winnowed by Turkish threshing machine. The Turkish threshing machine was tested at four feed rates of $0.2,0.3,0.4$ and $0.5 \mathrm{~kg} / \mathrm{s}$, four cylinder speeds of 11.99 (327), 14.84 (405), 17.96 (490) and 20.89 (570) m/s (r.p.m) and the same above mentioned moisture contents. All experiments were performed at the research farm of Rice Mechanization Center, Meet El-Deeba, Kafr ElSheikh Governorate. The characteristics of Giza-21 soybean crop are shown in Table 3. 
Gomaa, S.M. et al.

Table 3: Some physical properties of soybean variety (Giza-21) at grain and straw moisture content of $18.50 \%$ and $31.34 \%$

\begin{tabular}{|c|c|c|c|c|c|c|c|}
\hline \multirow{2}{*}{$\begin{array}{l}\text { No. of } \\
\text { sample }\end{array}$} & \multirow{2}{*}{$\begin{array}{c}\text { Plant } \\
\text { height, } \\
\text { cm }\end{array}$} & \multirow{2}{*}{$\begin{array}{l}\text { Height of } \\
\text { the first } \\
\text { pod, cm }\end{array}$} & \multicolumn{3}{|c|}{ Grain dimensions, $\mathrm{mm}$} & \multirow{2}{*}{$\begin{array}{c}\text { Mass of } \\
1000 \\
\text { seed, } \mathrm{g}\end{array}$} & \multirow{2}{*}{$\begin{array}{c}\text { Grain/stra } \\
\text { w ratio }\end{array}$} \\
\hline & & & Length & Width & Thickness & & \\
\hline 1 & 115 & 3 & 6.51 & 5.60 & 4.21 & 181 & $1: 1.26$ \\
\hline 2 & 92 & 5 & 6.54 & 5.66 & 4.33 & 180 & $1: 1.41$ \\
\hline 3 & 117 & 4 & 6.60 & 5.57 & 4.18 & 183 & $1: 1.30$ \\
\hline 4 & 90 & 7 & 6.54 & 5.61 & 4.33 & 182 & $1: 1.37$ \\
\hline 5 & 105 & 4 & 6.62 & 5.68 & 4.34 & 183 & $1: 1.33$ \\
\hline 6 & 92 & 8 & 6.60 & 5.54 & 4.21 & 183 & $1: 1.41$ \\
\hline 7 & 95 & 6 & 6.62 & 5.68 & 4.20 & 182 & $1: 1.31$ \\
\hline 8 & 120 & 4 & 6.50 & 5.60 & 4.35 & 181 & $1: 1.40$ \\
\hline 9 & 99 & 6 & 6.61 & 5.61 & 4.30 & 182 & $1: 1.30$ \\
\hline 10 & 105 & 5 & 6.50 & 5.68 & 4.33 & 183 & $1: 1.29$ \\
\hline Total & 1030 & 52 & 65.64 & 56.23 & 42.78 & 1820 & $1: 13.38$ \\
\hline Mean & 103 & 5.2 & 6.56 & 5.62 & 4.28 & 182 & $1: 1.338$ \\
\hline
\end{tabular}

a) Total grain losses: The total losses of combine harvester were those occurred in front and behind the combine during harvesting operations and it includes the following main sources:

i) Total header loss (sum of shatter, lodged, stalk and stubble loss).

Total header loss, $\%=\frac{\text { Total header loss, } \mathrm{kg} / \mathrm{fed} .}{\text { Total yield, } \mathrm{kg} / \mathrm{fed} .} \times 100$

ii) Unthreshed grain loss measurement (when using combine YanmarCA760):

Unthreshed grain loss, $\%=\frac{\text { Unthreshed grain loss, } \mathrm{kg} / \mathrm{fed} .}{\text { Total yield, } \mathrm{kg} / \mathrm{fed} .} \times 100$

iii) Threshed grain loss measurement (when using combine Yanmar-CA760):

Threshed grain loss, $\%=\frac{\text { Threshed grain loss, } \mathrm{kg} / \mathrm{fed} .}{\text { Total yield, } \mathrm{kg} / \mathrm{fed} .} \times 100$

Total losses, $\%=\frac{\mathrm{H}_{\mathrm{L}}+\mathrm{U}_{\mathrm{L}}+\mathrm{T}_{\mathrm{SL}}}{\mathrm{H}_{\mathrm{L}}+\mathrm{U}_{\mathrm{L}}+\mathrm{T}_{\mathrm{gL}}+\mathrm{T}_{\mathrm{Y}}} \times 100$

Where:

$\mathrm{H}_{\mathrm{L}} \quad=$ Total header loss, $\mathrm{kg} / \mathrm{fed}$.,

$\mathrm{UL}_{\mathrm{L}} \quad=$ Unthreshed grain loss, $\mathrm{kg} / \mathrm{fed}$.,

$\mathrm{T}_{\mathrm{gL}} \quad=$ Threshed grain loss, $\mathrm{kg} / \mathrm{fed}$.,

TY $\quad=$ Total grain yield, $\mathrm{kg} / \mathrm{fed}$.

b) Mechanical grain damage (visible and invisible):

i) Visible grain damage: It was determined by separating the damage grain by hand from a mass of 100 grams the samples were taken randomly from the threshed grain. The percentage of seed damage was calculated as follows:

Visible grain damage, $\%=\frac{\text { Mass of broken grains in sample, } g}{\text { Total mass of grains in sample, } g} \times 100^{----}$(5) 
ii) Invisible grain damage: A germination test was carried out using Petri dishes. The samples of these tests were taken randomly after separating the damage grain (visible damage). One hundred grains were put in Petri dish on a filter paper, covered with water and incubated at $25^{\circ} \mathrm{C}$ for $24 \mathrm{~h}$. the germinated grains were collected from each dish and expressed as a percentage of the original number of seed.

Total grain damage, $\%=$ (Visible grain damage, $\%$ + Invisible grain damage, $\%$ ) --- (6)

c) Fuel consumption: The fuel consumption per unit time is determined by measuring the volume of fuel consumed during harvesting or threshing time. The fuel consumption was experimentally determined by using a fuel consumption apparatus. Its capacity is about $750 \mathrm{ml}$. It has a reading scale divided into 15 sections with accuracy of $50 \mathrm{ml}$.

d) Consumed power: It was calculated by accurately measuring the decrease in fuel level in fuel tank immediately after carrying out each treatment. The following formula was used to determine consumed power (Barger et al. 1963).

$$
\mathrm{E}_{\mathrm{r}}=\left[\mathrm{F}_{\mathrm{c}} \times \frac{1}{3600}\right] \times \rho_{\mathrm{f}} \times \mathrm{L} \text {.C.V } \times 427 \times \eta_{\mathrm{th}} \times \eta_{\mathrm{m}} \times \frac{1}{75} \times \frac{1}{1.36}-\mathrm{kW}
$$

Where:

$\mathrm{E}_{\mathrm{r}}=$ Power requirements, $\mathrm{kW}$;

$\mathrm{F}_{\mathrm{C}}=$ Fuel consumption rate, $\mathrm{l} / \mathrm{h}$;

$\rho_{f}=$ Density of the fuel, $\mathrm{kg} / \mathrm{l}$ (for solar fuel) $=0.85 \mathrm{~kg} / \mathrm{l}$;

L.C.V = Lower calorific value of solar fuel (average, $10.000 \mathrm{kcal} / \mathrm{kg}$ );

$427=$ Thermo-mechanical equivalent, $\mathrm{kg} \cdot \mathrm{m} / \mathrm{kcal}$;

$\eta_{\text {th }}=$ Thermal efficiency of the engine, (considered to be about $35 \%$ for diesel engine), and

$\eta_{\mathrm{m}}=$ Mechanical efficiency of engine, $80 \%$ (considered to be about $80 \%$ for diesel engine).

\section{e) Cost analysis}

The cost of machine work was calculated by using the following formula (Awady, 1978):

$$
\mathrm{C}=\mathrm{P} / \mathrm{h}(1 / \mathrm{a}+\mathrm{i} / 2+\mathrm{t}+\mathrm{r})+(1.2 \mathrm{~W} \cdot \mathrm{S} . \mathrm{F})+\mathrm{m} / 144
$$

Where:

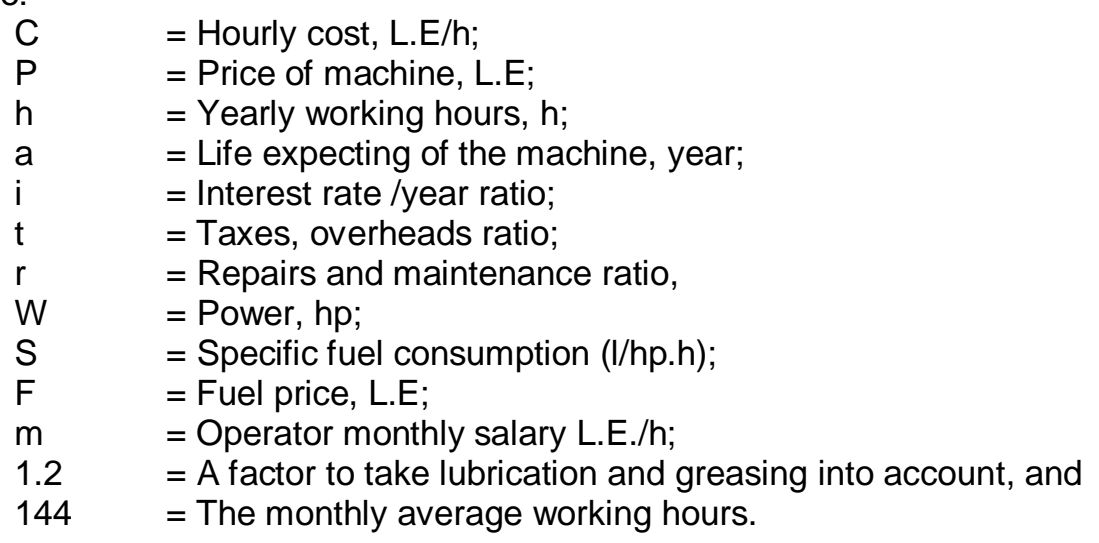


Gomaa, S.M. et al.

\section{Criterion cost:}

The criterion cost was estimated by using the following equation (Awady et al., 1982):

Operating $\cos \mathrm{t}=\frac{\text { Machinecost, L.E/h }}{\text { Effective field capacity, fed } . / \mathrm{h}}$, L.E/fed.

Comparative value: The comparative value was calculated by using the following equation:

Comparative value $=$ Operating cost (L.E/fed.) + Grain losses cost (L.E/fed.)

+ The difference in price between the whole grain and damage grain (L.E/fed.)

\section{Total losses, \%:}

\section{RESULTS AND DISCUSSION}

Fig. 3 indicate the effect of forward speed, cylinder speed and grain moisture content on the total grain losses. It can be noticed that the mean values of total losses reached $3.570,4.182,4.874$ and $5.748 \%$ at combine forward speeds of $1.4,1.9,2.6$ and $3.1 \mathrm{~km} / \mathrm{h}$, respectively by using cylinder speed of $9.87 \mathrm{~m} / \mathrm{s}$ and grain moisture content of $12.14 \%$. The other cylinder speeds and grain moisture contents gave the same above mentioned trend. It is remarkable that increasing combine forward speed tends to increase the total grain losses at all cylinder speeds and grain moisture contents. The reason is due to the exponential increase of all losses of different combine parts with increasing combine forward speed. Similar results obtained by (Abd El-Motaleb et al., 1999). The cylinder speeds of 9.87, 10.89, 12.59 and $13.95 \mathrm{~m} / \mathrm{s}$ gave the following values of total losses: $3.465,3.271,3.046$ and $2.815 \%$, respectively at forward speed of $1.9 \mathrm{~km} / \mathrm{h}$ and grain moisture content of $18.50 \%$. It is evident that the total losses decreased by $18.76 \%$ when the cylinder speed increased from 9.87 to $13.95 \mathrm{~m} / \mathrm{s}$ at the previous above mentioned factors. Otherwise, for all forward speed and grain moisture contents increasing the cylinder speeds leads to a decrease in the total losses. This attributed to the decrease of unthreshed and threshed grain losses by increasing cylinder speed.

Fig. 4 shows the effect of feed rate, cylinder speed and grain moisture content on total grain losses by using manual harvesting (traditional method) followed by mechanical threshing (Turkish thresher). It is clear that both cylinder speed and feed rate had small effect on total grain losses. On the other hand, an increase of total grain losses was observed by decreasing the grain moisture content from $22.41 \%$ to $12.14 \%$ where it increases by $39.32 \%$ at feed rate of $0.5 \mathrm{~kg} / \mathrm{s}$ and cylinder speed of $2.89 \mathrm{~m} / \mathrm{s}$. These increase in total losses may be attributed to the increase of manual harvesting and gathering at the lower moisture content (late of the season).

Results also showed a remarkable increase in total grain losses for manual and mechanical harvesting followed by mechanical threshing comparing with the combine harvester. However the maximum value of total grain losses reached 8.191 and 5.091 for manual harvesting followed by mechanical threshing and combine harvester, respectively under the same grain moisture content. 


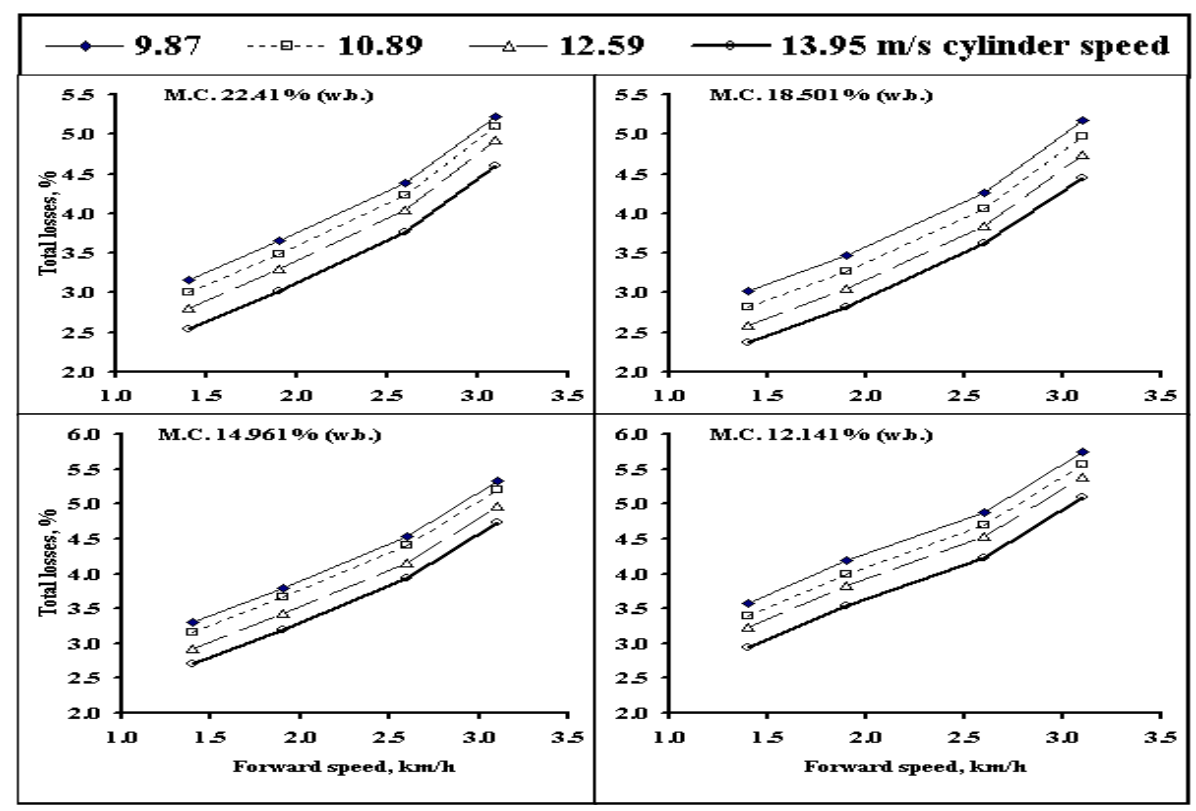

Fig. 3: Effect of forward speed, cylinder speed and grain moisture content on the total losses for combine harvester.

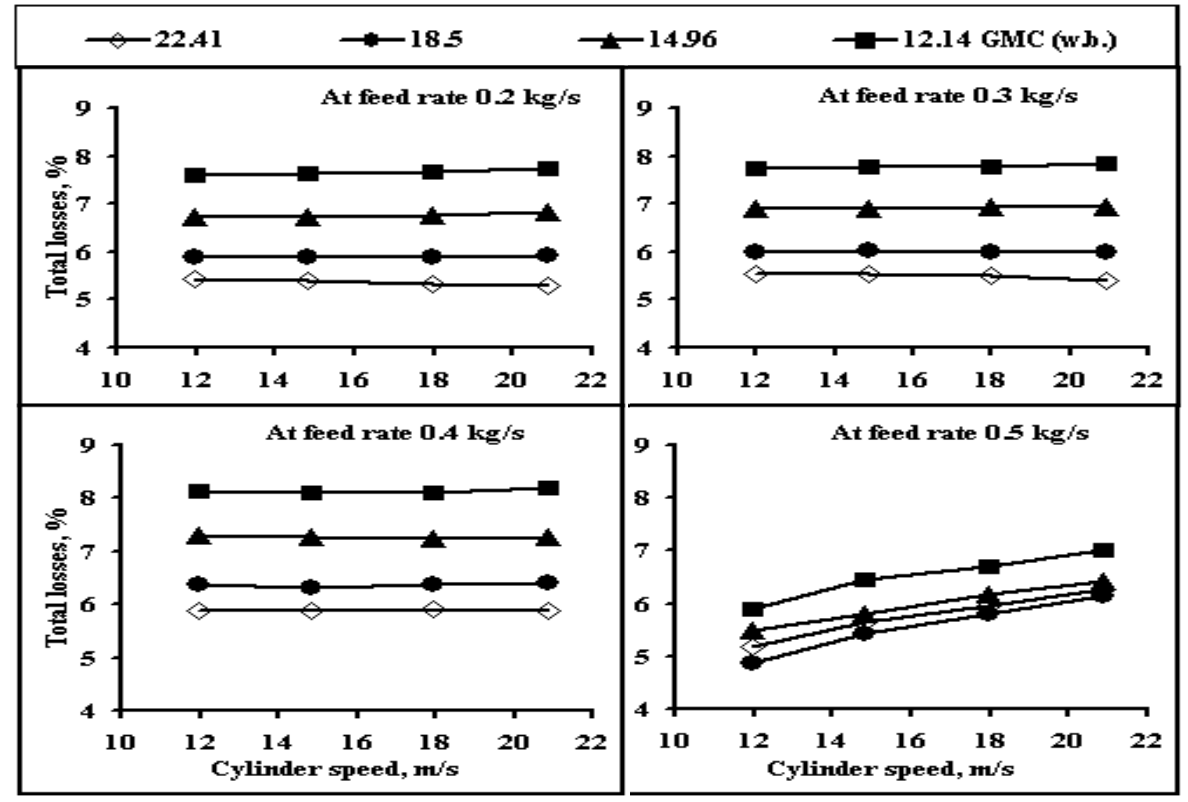

Fig. 4 : Effect of Feed rate, cylinder speed and grain moisture content on the total losses for Turkish threshing machine. 
Gomaa, S.M. et al.

\section{Total grain damage:}

Fig. 5 illustrates the effect of combine forward speed, cylinder speed and grain moisture content on total grain damage. It can be mentioned that total grain damage decreases by the increase of combine forward speed where it decreases by $43 \%$ when the combine forward speed increased from 1.4 to $3.1 \mathrm{~km} / \mathrm{h}$ at grain moisture content $18.5 \%$ and cylinder speed of 9.87 $\mathrm{m} / \mathrm{s}$. This may be due to the greater density of layer of material passing between the cylinder and the concave bars at high feed rate apparently provides more protection of the seeds. Thereby reducing the probability of repeated impacts by cylinder bars. This result agreed with that reported by (Nyborg, 1964). Results also, showed that if grain moisture content above or below $18,5 \%$ the total grain damage will be increased at all operation conditions of combine harvester. In regard to total grain damage, the increase of cylinder speed from 9,87 to $13,95 \mathrm{~m} / \mathrm{s}$ leads to increase the total grain damage by $266 \%$ at grain moisture content of $18,5 \%$ and combine forward speed of $1,4 \mathrm{~km} / \mathrm{h}$. Fig. 6 illustrates the effect of cylinder speed, feed rate and grain moisture content on total grain damage for Turkish threshing machine. The obtained values of total grain damage showed that the grain moisture content above or below $18,5 \%$ increases the total grain damage. The highest value was $7,003 \%$ which obtained from grain moisture content of $12,14 \%$, cylinder speed of $20,89 \mathrm{~m} / \mathrm{s}$ and feed rate of $0,2 \mathrm{~kg} / \mathrm{s}$. Dealing with the increase of cylinder speeds from 11,99 to $20,89 \mathrm{~m} / \mathrm{s}$ the total grain damage increased by $26 \%$. This may be due to the probability of repeated impacts by cylinder bars.

\section{Specific fuel consumption, l/kW.h:}

Table 4 summarizes the effect of combine forward speed, cylinder speed and grain moisture content on specific fuel consumption. It can be noticed that, the increase of combine forward speed, drum speed and grain moisture content increase the specific fuel consumption. The highest value of $0.235 \mathrm{l} / \mathrm{kW}$.h was recorded at combine forward speed of $3.1 \mathrm{~km} / \mathrm{h}$, cylinder speed of 13.95 and grain moisture content of $22.41 \%$. Results also, showed that Turkish thresher gave the lowest values of specific fuel consumption comparing with the combine harvester.

In the same manner the same trend was observed in case of using Turkish thresher whereas, the increase in both cylinder speed and grain moisture content tend to increase the specific fuel consumption. Also, results showed that the increase of feed rate increases the specific fuel consumption and the highest value of specific fuel consumption was $0.131 \mathrm{l} / \mathrm{kW}$.h at cylinder speed $20.89 \mathrm{~m} / \mathrm{s}$, feed rate of $0.5 \mathrm{~kg} / \mathrm{s}$ and grain moisture content of $22.41 \%$. it can be noticed that combine harvester gave the highest values of specific fuel consumption in all cases. 


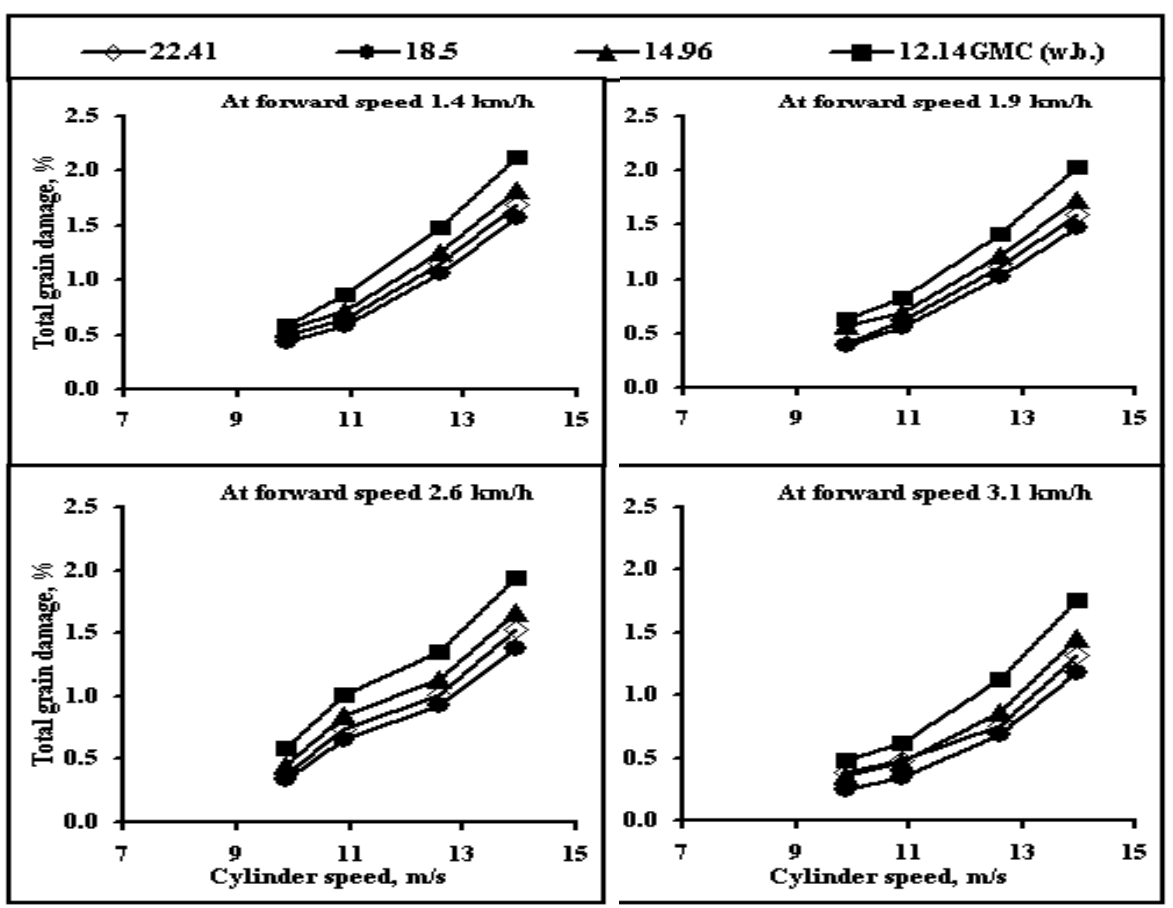

Fig. 5 : Effect of combine forward speed, cylinder speed and grain moisture content on total grain damage of soybean crop.

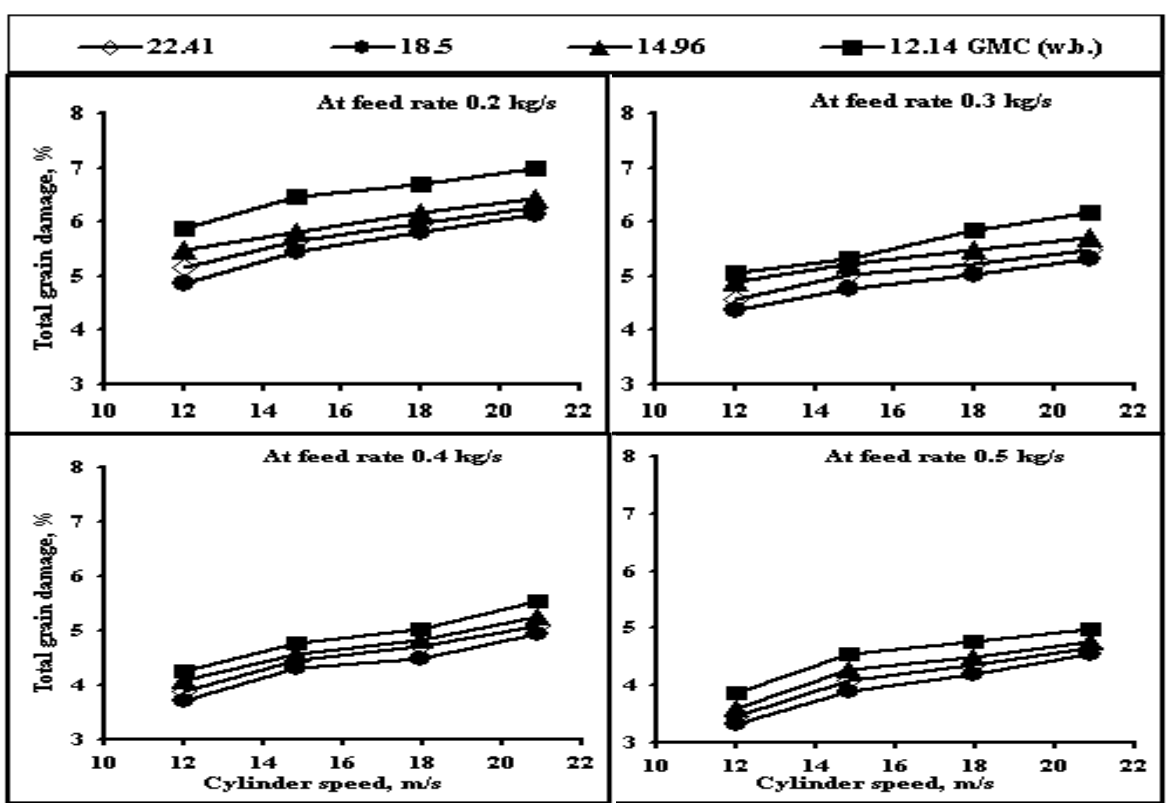

Fig. 6 : Effect of Feed rate, cylinder speed and grain moisture content on the total grain damage for Turkish threshing machine. 
Gomaa, S.M. et al.

Table 4: Effect of combine forward speed, cylinder speed and grain moisture content on specific fuel consumption, l/kW.h

\begin{tabular}{|c|c|c|c|c|c|}
\hline \multirow{2}{*}{ M.C. } & Forward & \multicolumn{4}{|c|}{ Cylinder speed, $\mathbf{~} / \mathbf{s}$} \\
\cline { 2 - 6 } & speed, $\mathbf{~ k m} / \mathbf{h}$ & $\mathbf{9 . 8 7}$ & $\mathbf{1 0 . 8 9}$ & $\mathbf{1 2 . 5 9}$ & $\mathbf{1 3 . 9 5}$ \\
\hline \multirow{4}{*}{$\mathbf{1 2 . 1 4}$} & $\mathbf{1 . 4}$ & 0.121 & 0.134 & 0.142 & 0.153 \\
\cline { 2 - 6 } & $\mathbf{1 . 9}$ & 0.128 & 0.139 & 0.150 & 0.161 \\
\cline { 2 - 6 } & $\mathbf{2 . 6}$ & 0.135 & 0.147 & 0.158 & 0.170 \\
\cline { 2 - 6 } & $\mathbf{3 . 1}$ & 0.143 & 0.155 & 0.167 & 0.179 \\
\hline \multirow{4}{*}{$\mathbf{1 4 . 9 6}$} & $\mathbf{1 . 4}$ & 0.142 & 0.153 & 0.165 & 0.177 \\
\cline { 2 - 6 } & $\mathbf{1 . 9}$ & 0.149 & 0.158 & 0.173 & 0.185 \\
\cline { 2 - 6 } & $\mathbf{2 . 6}$ & 0.158 & 0.169 & 0.180 & 0.191 \\
\cline { 2 - 6 } & $\mathbf{3 . 1}$ & 0.165 & 0.177 & 0.189 & 0.202 \\
\hline \multirow{4}{*}{$\mathbf{1 8 . 5}$} & $\mathbf{1 . 4}$ & 0.161 & 0.172 & 0.184 & 0.195 \\
\cline { 2 - 6 } & $\mathbf{1 . 9}$ & 0.169 & 0.180 & 0.193 & 0.207 \\
\cline { 2 - 6 } & $\mathbf{2 . 6}$ & 0.178 & 0.188 & 0.20 & 0.215 \\
\cline { 2 - 6 } & $\mathbf{3 . 1}$ & 0.187 & 0.196 & 0.208 & 0.224 \\
\cline { 2 - 6 } $\mathbf{2 2 . 4 1}$ & $\mathbf{1 . 4}$ & 0.183 & 0.190 & 0.198 & 0.206 \\
\cline { 2 - 6 } & $\mathbf{1 . 9}$ & 0.186 & 0.198 & 0.207 & 0.215 \\
\cline { 2 - 6 } & $\mathbf{2 . 6}$ & 0.195 & 0.205 & 0.215 & 0.224 \\
\hline
\end{tabular}

Comparative value for combine harvester, (L.E/fed.):

Data listed in Table 5 shows the effect of combine forward speed, cylinder speed and grain moisture content on comparative value.

Table 5 : Effect of combine forward speed, cylinder speed and grain moisture content on the comparative value for combine harvester

\begin{tabular}{|c|c|c|c|c|c|}
\hline \multirow{2}{*}{$\begin{array}{c}\text { Forward } \\
\text { speed, } \\
\mathbf{k m} / \mathbf{h}\end{array}$} & $\begin{array}{c}\text { Cylinder } \\
\text { speed, } \\
\mathbf{m} / \mathbf{s}\end{array}$ & \multicolumn{4}{|c|}{ Mean values of comparative value, L.E/fed. } \\
\cline { 2 - 6 } & 9.870 & $\mathbf{2 2 . 4 1}$ & $\mathbf{1 8 . 5 0}$ & $\mathbf{1 4 . 9 6}$ & $\mathbf{1 2 . 1 4}$ \\
\hline \multirow{4}{*}{$\mathbf{1 . 4}$} & 907.921 & 293.640 & 295.075 & 296.021 \\
\cline { 2 - 6 } & 10.89 & 306.223 & 290.815 & 293.928 & 294.950 \\
\cline { 2 - 6 } & 12.59 & 308.150 & 291.404 & 295.309 & 298.099 \\
\cline { 2 - 6 } & 13.95 & 309.091 & 292.980 & 297.721 & 299.625 \\
\hline \multirow{4}{*}{$\mathbf{1 . 9}$} & 9.870 & 287.187 & 271.972 & 274.939 & 279.450 \\
\cline { 2 - 6 } & 10.89 & 285.220 & 269.229 & 274.233 & 277.463 \\
\cline { 2 - 6 } & 12.59 & 287.249 & 269.736 & 275.163 & 280.835 \\
\cline { 2 - 6 } & 13.95 & 286.604 & 270.220 & 276.251 & 281.628 \\
\hline \multirow{4}{*}{$\mathbf{4}$} & 9.870 & 282.721 & 268.843 & 270.293 & 272.729 \\
\cline { 2 - 6 } & 10.89 & 281.290 & 265.901 & 269.524 & 270.829 \\
\cline { 2 - 6 } & 12.59 & 282.501 & 266.152 & 269.879 & 274.166 \\
\cline { 2 - 6 } & 13.95 & 282.579 & 266.878 & 271.339 & 274.413 \\
\hline \multirow{4}{*}{3.1} & 9.870 & 301.729 & 287.596 & 284.361 & 288.453 \\
\cline { 2 - 6 } & 10.89 & 299.533 & 283.571 & 282.697 & 285.584 \\
\cline { 2 - 6 } & 12.59 & 300.488 & 282.272 & 281.707 & 287.883 \\
\cline { 2 - 6 } & 13.95 & 299.549 & 281.347 & 283.840 & 288.908 \\
\hline
\end{tabular}


It can be stated that, increasing the forward speed from 1.4 to $2.6 \mathrm{~km} / \mathrm{h}$ tends to decrease the comparative value from 290.815 to $265.901 \mathrm{~L}$.E/fed., at cylinder speed of $10.89 \mathrm{~m} / \mathrm{s}$ and grain moisture content of $18.50 \%$. Meanwhile, it was increased from 265.901 to $283.571 \mathrm{~L}$.E/fed., by increasing the combine forward speed from 2.6 to $3.1 \mathrm{~km} / \mathrm{h}$ at the above mentioned cylinder speed and grain moisture content. The other cylinder speeds and grain moisture contents had the same above mentioned trend.

\section{Comparative value for traditional method, L.E/fed.:}

Table 6 shows the effect of feed rate, cylinder speed and grain moisture content on the comparative value for traditional method. It can be stated that, increasing the feed rate from 0.2 to $0.5 \mathrm{~kg} / \mathrm{s}$ leads to decrease the comparative value from 500.212 to $398.307,486.411$ to $394.295,499.101$ to 409.702 and from 510.002 to $421.554 \mathrm{~L} . \mathrm{E} / \mathrm{fed}$. at cylinder speed of $11.99 \mathrm{~m} / \mathrm{s}$ and grain moisture contents of $22.41,18.50,14.96$ and $12.14 \%$, respectively. The other cylinder speeds gave the same above mentioned trend. Results showed a positive relationship between the comparative value and cylinder speed at all feed rates and grain moisture content. The obtained comparative values were: $510.002,514.228,516.603$ and $520.244 \mathrm{~L}$.E/fed. at cylinder speeds of $11.99,14.84,17.96$ and $20.89 \mathrm{~m} / \mathrm{s}$, respectively, with the feed rate of $0.2 \mathrm{~kg} / \mathrm{s}$ and grain moisture content of $12.14 \%$.

Table 6: Effect of feed rate, cylinder speed and grain moisture content on the comparative value for traditional method

\begin{tabular}{|c|c|c|c|c|c|}
\hline \multirow{2}{*}{$\begin{array}{c}\text { Feed } \\
\text { rate, } \\
\mathbf{k g} / \mathbf{s}\end{array}$} & \multirow{2}{*}{$\begin{array}{c}\text { Cylinder } \\
\text { speed, } \\
\mathbf{m} / \mathbf{s}\end{array}$} & \multicolumn{4}{|c|}{$\begin{array}{c}\text { Mean values of comparative value for traditional } \\
\text { method, L.E/fed. }\end{array}$} \\
\cline { 3 - 6 } & & $\mathbf{2 2 . 4 1}$ & $\mathbf{1 8 . 5 0}$ & $\mathbf{1 4 . 9 6}$ & $\mathbf{1 2 . 1 4}$ \\
\hline \multirow{4}{*}{$\mathbf{0 . 2}$} & 11.99 & 500.212 & 486.411 & 499.101 & 510.002 \\
\cline { 2 - 6 } & 14.84 & 502.522 & 490.183 & 499.711 & 514.228 \\
\cline { 2 - 6 } & 17.96 & 503.493 & 493.170 & 501.850 & 516.603 \\
\cline { 2 - 6 } & 20.89 & 504.460 & 497.458 & 505.523 & 520.244 \\
\hline \multirow{4}{*}{$\mathbf{0 . 3}$} & 11.99 & 443.846 & 435.824 & 451.450 & 460.897 \\
\cline { 2 - 6 } & 14.84 & 448.447 & 439.587 & 454.675 & 465.586 \\
\cline { 2 - 6 } & 17.96 & 449.655 & 441.840 & 457.345 & 468.834 \\
\cline { 2 - 6 } & 20.89 & 450.323 & 445.488 & 459.979 & 473.996 \\
\hline \multirow{4}{*}{$\mathbf{0 . 4}$} & 11.99 & 415.240 & 408.217 & 424.180 & 434.019 \\
\cline { 2 - 6 } & 14.84 & 422.024 & 415.600 & 429.621 & 439.586 \\
\cline { 2 - 6 } & 17.96 & 424.976 & 416.355 & 432.264 & 443.329 \\
\cline { 2 - 6 } & 20.89 & 427.092 & 422.314 & 437.754 & 451.109 \\
\hline \multirow{4}{*}{$\mathbf{0 . 5}$} & 11.99 & 398.307 & 394.295 & 409.702 & 421.554 \\
\cline { 2 - 6 } & 14.84 & 407.140 & 400.509 & 417.430 & 429.316 \\
\cline { 2 - 6 } & 17.96 & 411.391 & 405.915 & 419.432 & 432.136 \\
\cline { 2 - 6 } & 20.89 & 414.898 & 411.191 & 423.338 & 436.608 \\
\hline
\end{tabular}

\section{Conclusion}

Form the above results the following conclusions are drived:

1. Combine harvester (Yanmar-CA760) is strongly recommended since it gives lower losses, damage and costs, and higher performance efficiency 


\section{Gomaa, S.M. et al.}

compared to manual harvesting and gathering following by mechanical threshing and winnowing using Turkish thresher.

2. The optimum operating conditions for the combine harvest or (YanmarCA760) are at forward speed of $2.6 \mathrm{~km} / \mathrm{h}$, cylinder speed of $10.89 \mathrm{~m} / \mathrm{s}$ and grain moisture content of $18.50 \%$.

3. The optimum operating conditions for manual harvesting and gathering followed by mechanical threshing and winnowing using Turkish thresher at the same time was at feed rate of $0.5 \mathrm{~kg} / \mathrm{s}$, cylinder speed of $11.99 \mathrm{~m} / \mathrm{s}$ and grain moisture content of $18.50 \%$.

4. The lowest comparative value for combine harvester (265.901 L.E/fed.,) was obtained at cylinder speed of $10.89 \mathrm{~m} / \mathrm{s}$, forward speed $2.6 \mathrm{~km} / \mathrm{h}$ and grain moisture content of $18.50 \%$. Meanwhile, it was reached $(394.295$ L.E/fed.,) at cylinder speed of $11.99 \mathrm{~m} / \mathrm{s}$, feed rate of $0.5 \mathrm{~kg} / \mathrm{s}$ and grain moisture content $18.50 \%$ for traditional method.

\section{REFERENCES}

Abd El-Motaleb, I.A.; M.M. Ibrahim and I.S. Yousef (1999). A study on harvesting of soybean and sunflower crops. Misr J. Agric. Eng., 16(2): 337-351.

Awady, M.N. (1978). Engineering of tractors and agricultural machinery. In Arabic, Text. Col. of Agric. Ain Shams Univ., : 164-167.

Awady, M.N.; E.Y. Ghoniem and A.I. Hashish (1982). A critical comparison between wheat combine harvesters under Egyptian conditions. Res. Bul. 1920, Fac. of Agric. Ain Shams Univ.: 13p.

Baiomy, M.A.; A.H.A. Mohamed ; I. Yehia and E.M. Arif (1999). Performance of AMRI and Gabr threshers for soybean. Misr J. Agric. Eng., 16(4): 340-350.

Barger H.; J.L. Edohl, W.M. Carletor and E.G. Mchibben (1963). Tractor and their power units. $2^{\text {nd }}$ ed, Wiley Sons Inc., New York, U.S.A.

Dunn, W.E.; W.R. Nave and B.J. Butler (1973). Combine header component losses in soybeans. Trans. of the ASAE 16(6): 1032-1035.

Fernando, S.; A. Hanna and C. Mesquita (2004). Soybean threshing mechanism development and testing. Trans. of the ASAE, 47(3): 599605.

Jung, R. (1988). Measuring soybean harvesting losses. Eng. Section / Ridgetown college of Agric. Technology, Government of Ontario, Canda, ISSN 1198-712X.

McDonald, M.B., Jr. (1985). Physical seed quality of soybean. Seed Science and Technology 13: 601-628.

Mesquita, C.M. (1994). Tropical soybean improvement and production, FAO, plant production and protection series No. 27 "Harvesting methods". Brazilian Agric. Res. Enterprise. National Soybean Res. Center. 161169.

Nave, W.R.; D.E. Tates; J.L. Butler and R.R. Yoerger (1973). Soybean harvesting, USDA, ARS, NC-7. Peoria, II. July. 
Nyborg, E.O. (1964). Grain combine loss characteristics. Trans. of the ASAE, 12(6): 727-732.

Sharma, K.D. and R.S. Devnani (1980). Threshing studies on soybean and cowpea. AMA, Winter, 11 (3): 65-68.

Tandon, S.K. and J.S. Panwar (1989). Status of mechanization of harvesting and threshing of soybean in India. AMA, 20(1): 55-60.

Vejasit, A. and V.M. Salokhe (2004). Studies on machine-crop parameters of an axial flow thresher for threshing soybean. Gigr J. of Scientific Research and development. Manuscript PM04004.

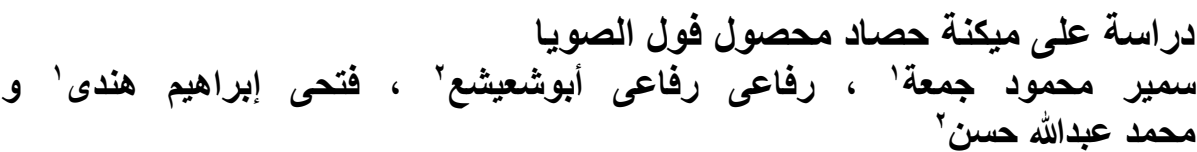

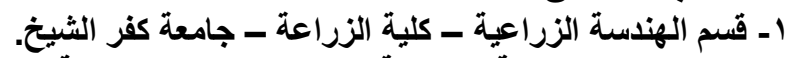

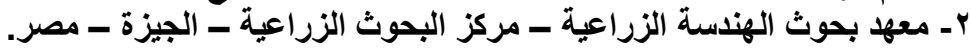

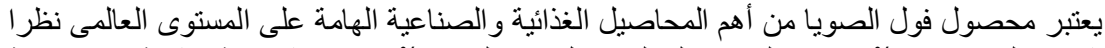

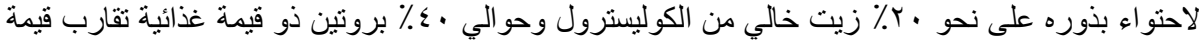

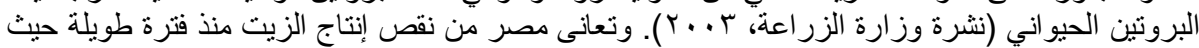

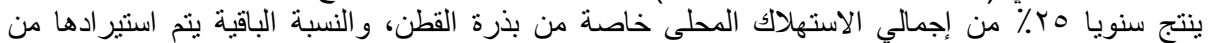

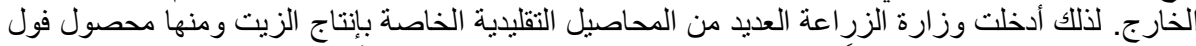

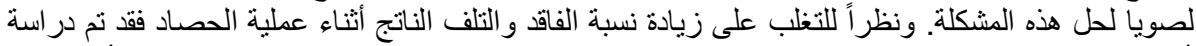

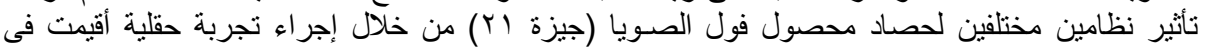

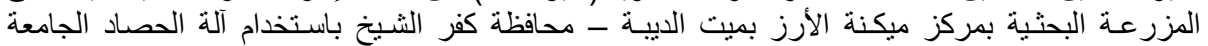

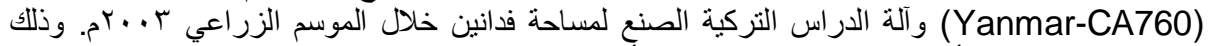

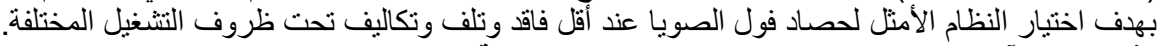
وقد تم تقييم آلتي الحصاد والدارس من خلاسل المعاملات التالية:

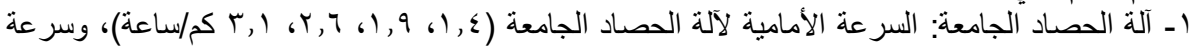

درفيل الدراس ( ( T

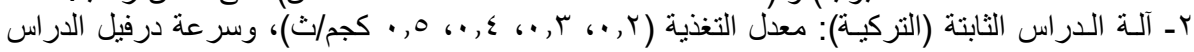

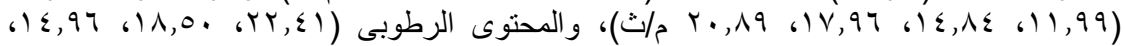

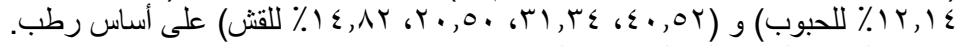

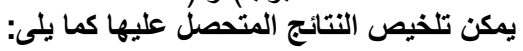

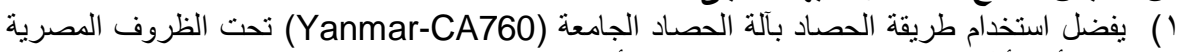
حيث أنها أقل فى الفو اقد والتلف والتكاليف وأعلى كفاءة مقارنة بطريقة الحصاد والتجميع اليدوى ثمثر الأر اس والتذرية بآلة الدراس التركية.

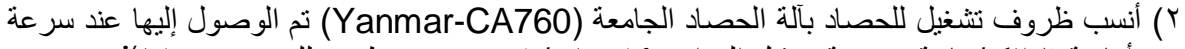

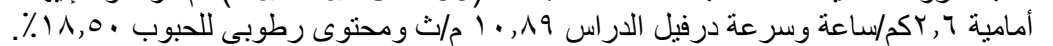

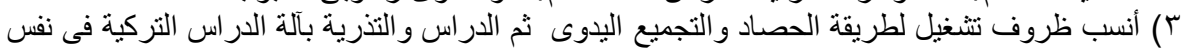

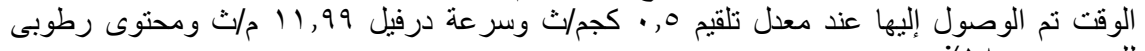

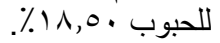

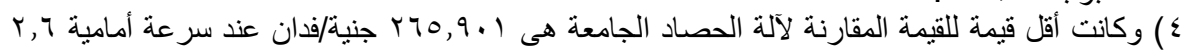

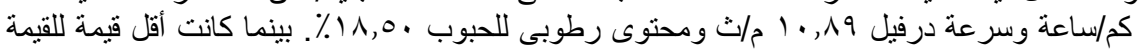

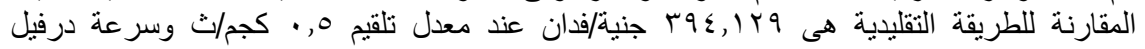
11,99 1 م/ث عند نفس المحتوى الرطوبى. 